\title{
MENINGKATKAN MOTIVASI DAN PRESTASI BELAJAR IPA DENGAN MENERAPKAN METODE PEMBERIAN BALIKAN
}

\author{
Adi Apriadi Adiansha \\ Pascasarjana Universitas Negeri Jakarta \\ e-mail: adiapriadiadiansyah@gmail.com
}

\begin{abstract}
Abstrak
Penelitian ini ditujukan untuk meningkatkan motivasi dan prestasi belajar pada mata pelajaran IPA dengan menerapkan metode pemberian balikan siswa. Subjek penelitian adalah peserta siswa Kelas III.a SDN 02 Kota Bima yang berjumlah 36 siswa. Jumlah tersebut terdiri atas 12 siswa laki-laki dan 24 siswa perempuan. Jenis penelitin ini adalah penelitian tindakan kelas yang dilakukan dalam tiga siklus. Masing-masing siklus terdiri dari tahap perencanaan, pelaksanaan tindakan, observasi, evaluasi dan refleksi. Data aktivitas belajar siswa diperoleh dengan cara observasi sedangkan data hasil menghitung kemampuan operasi hitung pecahan bentuk aljabar siswa diperoleh dari pemberian tes pada tiap akhir siklus. Hasil penelitian menunjukkan bahwa pembelajaran pembelajaran dengan metode pemberian balikan memiliki dampak positif dalam meningkatkan prestasi belajar siswa yang ditandai dengan peningkatan ketuntasan belajar siswa dalam setiap siklus, yaitu siklus I $(69,44$, siklus II $(80,56 \%)$, siklus III $(88,89 \%)$. Dengan demikian dapat disimpulkan bahwa penerapan pemberian balikan telah berhasil terlaksana dalam upaya meningkatkan motivasi dan prestasi belajar pada mata pelajaran IPA.
\end{abstract}

Kata Kunci: motivasi, prestasi, metode pemberian balikan

\section{INCREASING THE MOTIVATION AND ACHIEVEMENT OF SCIENCE LEARNING BY APPLYING THE GIVING METHODS}

\begin{abstract}
This research is aimed to improve motivation and learning achievement in science subjects by applying the method of giving students feedback. The subjects of the study were students of Class III.a SDN 02 Kota Bima, amounting to 36 students. The number consists of 12 male students and 24 female students. This type of research is classroom action research conducted in three cycles. Each cycle consists of planning, implementation, observation, evaluation and reflection. Student learning activity data obtained by means of observation while the data results calculate the ability to calculate the fractional operations of algebra students form obtained from the test at the end of each cycle. The result of the research shows that learning learning with reverse method has a positive impact in improving student achievement which is marked by the improvement of students' learning mastery in every cycle, that is cycle I $(69,44$, cycle II $(80,56 \%)$, cycle III $(88,89 \%)$ Thus it can be concluded that the application of feedback has been successfully implemented in an effort to improve motivation and learning achievement on science subjects.
\end{abstract}

Keywords: motivation, achievment, feedback method

PENDAHULUAN

Tugas utama guru adalah bertanggung jawab membantu anak didik dalam hal belajar. Dalam proses belajar mengajar, gurulah yang menyampaikan pelajaran, memecahkan masalah-masalah yang terjadi dalam kelas, membuat evaluasi belajar siswa, baik sebelum, sedang maupun sesudah pelajaran berlangsung (Combs, 1984:11-13). Untuk memainkan peranan dan melaksanakan tugas-tugas itu, seorang guru diharapkan memiliki kemampuan professional yang tinggi. Dalam hubungan ini maka untuk mengenal 
siswa-siswanya dengan baik, guru perlu memiliki kemampuan untuk melakukan diagnosis serta mengenal dengan baik caracara yang paling efektif untuk membantu siswa tumbuh sesuai dengan potensinya masing-masing.

Proses pembelajaran yang dilakukan guru memang dibedakan keluasan cakupannya, tetapi dalam konteks kegiatan belajar mengajar mempunyai tugas yang sama. Maka tugas mengajar bukan hanya sekedar menuangkan bahan pelajaran, tetapi teaching is primarily and always the stimulation of learner (Wetherington, 1986:131-136), dan mengajar tidak hanya dapat dinilai dengan hasil penguasaan mata pelajaran, tetapi yang terpenting adalah perkembangan pribadi anak, sekalipun mempelajari pelajaran yang baik, akan memberikan pengalaman membangkitkan bermacammacam sifat, sikap dan kesanggupan yang konstruktif.

Dengan tercapainya tujuan dan kualitas pembelajaran, maka dikatakan bahwa guru telah berhasil dalam mengajar. Keberhasilan kegiatan belajar mengajar tentu saja diketahui setelah diadakan evalusi dengan berbagai faktor yang sesuai dengan rumusan beberapa tujuan pembelajaran. Sejauh mana tingkat keberhasilan belajar mengajar, dapat dilihat dari daya serap anak didik dan persentase keberhasilan anak didik dalam mencapai tujuan pembelajaran khusus. Jika hanya tujuh puluh lima persen atau lebih dari jumlah anak didik yang mengikuti proses belajar mengajar mencapai taraf keberhasilan kurang (di bawah taraf minimal), maka proses belajar mengajar berikutnya hendaknya ditinjau kembali.

Setiap akan mengajar, guru perlu membuat persiapan mengajar dalam rangka melaksanakan sebagian dari rencana bulanan dan rencana tahunan. Dalam perisiapan itu sudah terkandung tentang, tujuan mengajar, pokok yang akan diajarkan, metode mengajar, bahan pelajaran, alat peraga dan teknik evaluasi yang digunakan. Karena itu setiap guru harus memahami benar tentang tujuan mengajar, secara khusus memilih dan menentukan metode mengajar sesuai dengan tujuan yang hendak dicapai, cara memilih, menentukan dan menggunakan alat peraga, cara membuat tes dan menggunakannya, dan pengetahuan tentang alat-alat evaluasi.

Sementara itu teknologi pembelajaran adalah salah satu dari aspek tersebut yang cenderung diabaikan oleh beberapa pelaku pendidikan, terutama bagi mereka yang menganggap bahwa sumber daya manusia pendidikan, sarana dan prasarana pendidikanlah yang terpenting. Padahal kalau dikaji lebih lanjut, setiap pembelajaran pada semua tingkat pendidikan baik formal maupun non formal, haruslah berpusat pada kebutuhan perkembangan anak sebagai calon individu yang unik, sebagai makhluk sosial, dan sebagai calon manusia seutuhnya.

Hal tersebut dapat dicapai apabila dalam aktivitas belajar mengajar, guru senantiasa memanfaatkan teknologi pembelajaran yang mengacu pada pembelajaran dengan pemberian balikan dalam penyampaian materi dan mudah diserap peserta didik atau siswa berbeda.

Khususnya dalam pembelajaran IPA, agar siswa dapat memahami materi yang disampaikan guru dengan baik, maka proses pembelajaran dengan pemberian balikan, guru akan memulai membuka pelajaran dengan menyampaikan kata kunci, tujuan yang ingin dicapai, baru memaparkan isi dan diakhiri dengan memberikan soal-soal kepada siswa.

Dari latar belakang masalah tersebut, maka perlu dilakukan penelitian "Meningkatkan Motivasi dan Prestasi Belajar IPA dengan Menerapkan Metode Pemberian Balikan".

\section{METODE}

Penelitian ini merupakan penelitian tindakan (action research), karena penelitian dilakukan untuk memecahkan masalah pembelajaran di kelas. Penelitian ini juga termasuk penelitian deskriptif, 
sebab menggambarkan bagaimana suatu teknik pembelajaran diterapkan dan bagaimana hasil yang diinginkan dapat dicapai.

\section{Rancangan Penelitian}

Menurut pengertiannya penelitian tindakan adalah penelitian tentang hal-hal yang terjadi dimasyarakat atau sekolompok sasaran, dan hasilnya langsung dapat dikenakan pada masyarakat yang bersangkutan (Arikunto, 2002:82). Ciri atau karakteristik utama dalam penelitian tindakan adalah adanya partisipasi dan kolaborasi antara peneliti dengan anggota kelompok sasaran. Penelitian tidakan adalah satu strategi pemecahan masalah yang memanfaatkan tindakan nyata dalam bentuk proses pengembangan invovatif yang dicoba sambil jalan dalam mendeteksi dan memecahkan masalah. Dalam prosesnya pihak-pihak yang terlibat dalam kegiatan tersebut dapat saling mendukung satu sama lain.

Sedangkan tujuan penelitian tindakan harus memenuhi beberapa prinsip sebagai berikut:

1. Permasalahan atau topik yang dipilih harus memenuhi kriteria, yaitu benarbenar nyata dan penting, menarik perhatian dan mampu ditangani serta dalam jangkauan kewenangan peneliti untuk melakukan perubahan.

2. Kegiatan penelitian, baik intervensi maupun pengamatan yang dilakukan tidak boleh sampai mengganggu atau menghambat kegiatan utama.

3. Jenis intervensi yang dicobakan harus efektif dan efisien, artinya terpilih dengan tepat sasaran dan tidak memboroskan waktu, dana dan tenaga.

4. Metodologi yang digunakan harus jelas, rinci, dan terbuka, setiap langkah dari tindakan dirumuskan dengan tegas sehingga orang yang berminat terhadap penelitian tersebut dapat mengecek setiap hipotesis dan pembuktiannya.

5. Kegiatan penelitian diharapkan dapat merupakan proses kegiatan yang berkelanjutan (on-going), mengingat bahwa pengembangan dan perbaikan terhadap kualitas tindakan memang tidak dapat berhenti tetapi menjadi tantangan sepanjang waktu. (Arinkunto, 2002:82-83).

Sesuai dengan jenis penelitian yang dipilih, yaitu penelitian tindakan, maka penelitian ini menggunakan model penelitian tindakan dari Kemmis dan Taggart (1988:14), yaitu berbentuk spiral dari siklus yang satu ke siklus yang berikutnya. Setiap siklus meliputi planning (rencana), action (tindakan), observation (pengamatan), dan reflection (refleksi). Langkah pada siklus berikutnya adalah perncanaan yang sudah direvisi, tindakan, pengamatan, dan refleksi. Sebelum masuk pada siklus 1 dilakukan tindakan pendahuluan yang berupa identifikasi permasalahan.

Penelitian ini dilaksanakan selama tiga siklus/putaran.Observasi dibagi dalam tiga putaran, yaitu putaran 1,2 , dan 3, dimana masing putaran dikenai perlakuan yang sama (alur kegiatan yang sama) dan membahas satu sub pokok bahasan yang diakhiri dengan tes formatif di akhir masing putaran. Dibuat dalam tiga putaran dimaksudkan untuk memperbaiki sistem pengajaran yang telah dilaksanakan.

\section{Tempat dan Waktu Penelitian}

Tempat penelitian adalah tempat yang digunakan dalam melakukan penelitian untuk memperoleh data yang diinginkan. Penelitian ini bertempat di SDN 02 Kota Bima.

Waktu penelitian adalah waktu berlangsungnya penelitian atau saat penelitian ini dilangsungkan. Penelitian ini dilaksanakan pada bulan November semester ganjil 2016/2017.

\section{Subyek Penelitian}

Subyek penelitian adalah siswasiswi Kelas III.a SDN 02 Kota Bima yang berjumlah 36 siswa pada pokok bahasan sistem persamaan dua variabel.

\section{Prosedur Penelitian}

Penelitian ini dilakukan melalui tiga tahap, yaitu: (1) tahap persiapan, (2) tahap pelaksanaan, dan (3) tahap penyelesaian. 
1. Tahap Persiapan

Kegiatan yang dilakukan dalam
tahap persiapan ini adalah
mempersiapkan segala sesuatu yang
berhubungan dengan pelaksanaan
penelitian. Dalam kegiatan ini
diharapkan pelaksanaan penelitian akan
berjalan lancer dan mencapai tujuan
yang diinginkan. Kegiatan persiapan ini
meliputi:(1) kajian pustaka, (2)
pengurusan administrasi perijinan, (3)
penyusunan rancangan penelitian, (4)
orientasi lapangan, dan (5) penyusunan
instrumen penelitian.

2. Tahap Pelaksanaan

Pada tahap pelaksanaan penelitian ini, kegiatan yang dilakukan meliputi:(1) pengumpulan data melalui tes dan pengamatan yang dilakukan persiklus, (2) diskusi dengan pengamat untuk memecahkan kekurangan dan kelemahan selama proses belajar mengajar persiklus, (3) menganalisi data hasil penelitian persiklus, menafsirkan hasil analisis data, dan (5) bersama-sama dengan pengamat menentukan langkah perbaikan untuk siklus berikutnya.

3. Tahap Penyelesaian

Dalam tahap penyelesaian, kegiatan yang dilakukan meliputi:(1) menyusun draf laporan penelitian, mendiskusikan draf laporan penelitian, (3) merevisi draf laporan penelitian, (4) menyusun naskah laporan penelitian, dan (5) menggandakan laporan penelitian.

\section{Instrumen Penelitian}

Instrumen yang digunakan dalam penelitian ini terdiri dari:

\section{Rencana Pelajaran (RP)}

Yaitu merupakan perangkat pembelajaran yang digunakan sebagai pedoman guru dalam mengajar dan disusun untuk tiap putaran. Masingmasing RP berisi kompetensi dasar, indikator pencapaian hasil belajar, tujuan pembelajaran khusus, dan kegiatan belajar mengajar.

2. Lembar Kegiatan Siswa
Lembar kegiatan ini yang dipergunakan siswa untuk membantu proses pengumpulan data hasil kegiatan pemberian tugas.

3. Tes formatif

Tes ini disusun berdasarkan tujuan pembelajaran yang akan dicapai, digunakan untuk mengukur kemampuan pemahaman konsep matematika pada pokok bahasan sistem persamaan dua variabel. Tes formatif ini diberikan setiap akhir putaran. Bentuk soal yang diberikan adalah pilihan guru (objektif). Sebelumnya soal-soal ini berjumlah 46 soal yang telah diujicoba, kemudian penulis mengadakan analisis butir soal tes yang telah diuji validitas dan reliabilitas pada tiap soal. Analisis ini digunakan untuk memilih soal yang baik dan memenuhi syarat digunakan untuk mengambil data.

4. Uji Coba Instumen Penelitian

Untuk menguji keakuratan dalam menjaring data, maka instrumen penelitian ini perlu diujicobakan terlebih dahulu. Uji coba instrumen penelitian dilakukan di luar sasaran penelitian. Secara umum ujicoba dimaksudkan untuk memperoleh (1) validitas, (2) relabilitas, (3) derajad kesukaran, dan (4) daya beda instrumen.

\section{Teknik Analisis Data}

Untuk mengetahui keefektivan suatu metode dalam kegiatan pembelajaran perlu diadakan analisa data. Pada penelitian ini menggunakan teknik analisis deskriptif kualitatif, yaitu suatu metode penelitian yang bersifat menggambarkan kenyataan atau fakta sesuai dengan data yang diperoleh dengan tujuan untuk mengetahui prestasi belajar yang dicapai siswa juga untuk memperoleh respon siswa terhadap kegiatan pembelajaran serta aktivitas siswa selama proses pembelajaran.

Untuk menganalisis tingkat keberhasilan atau persentase keberhasilan siswa setelah proses belajar mengajar setiap putarannya dilakukan dengan cara memberikan evaluasi berupa soal tes tertulis pada setiap akhir putaran. 


\section{HASIL DAN PEMBAHASAN Hasil}

Data penelitian yang diperoleh adalah data observasi berupa pengamatan pengelolaan pembelajaran pembelajaran dengan metode pemberian balikan, dan data tes formatif siswa pada setiap siklus.

Data lembar observasi diambil dari dua pengamatan yaitu data pengamatan pengelolaan pembelajaran pembelajaran dengan metode pemberian balikan yang digunakan untuk mengetahui pengaruh penerapan pembelajaran dengan metode pemberian balikan dalam meningkatkan prestasi.

Data tes formatif untuk mengetahui peningkatan prestasi belajar siswa setelah diterapkan pembelajaran pembelajaran dengan metode pemberian balikan.

\section{Siklus I}

\section{a. Tahap Perencanaan}

Pada tahap ini peneliti mempersiapkan perangkat pembelajaran yang terdiri dari rencana pelajaran 1 , LKS 1 , soal tes formatif 1 dan alat-alat pengajaran yang mendukung. Selain itu juga dipersiapkan lembar observasi pengolahan pembelajaran dengan metode pemberian balikan, dan lembar observasi aktivitas guru dan siswa.

b. Tahap Kegiatan dan Pelaksanaan

Pelaksanaan kegiatan belajar mengajar untuk siklus I dilaksanakan pada tanggal 10 September 2016 di Kelas III.a dengan jumlah siswa 36 siswa. Dalam hal ini peneliti bertindak sebagai guru, sedangkan yang bertindak sebagai pengamat adalah dua orang guru. Adapun proses belajar mengajar mengacu pada rencana pelajaran yang telah dipersiapkan. Pengamatan (observasi) dilaksanakan bersamaan dengan pelaksaaan belajar mengajar.

Pada akhir proses belajar mengajar siswa diberi tes formatif I dengan tujuan untuk mengetahui tingkat keberhasilan siswa dalam proses belajar mengajar yang telah dilakukan.
Berdasarkan hasil penelitian yang diperoleh, bahwa aspek-aspek yang mendapatkan kriteria kurang baik adalah memotivasi siswa, menyampaikan tujuan pembelajaran, pengelolaan waktu, dan siswa antusias. Keempat aspek yang mendapat penilaian kurang baik di atas, merupakan suatu kelemahan yang terjadi pada siklus I. Dan akan dijadikan bahan kajian untuk refleksi dan revisi yang akan dilakukan pada siklus II.

Aktivitas guru yang paling dominan pada siklus I adalah membimbing dan mengamati siswa dalam menemukan konsep yaitu 18,33\%. Aktivitas lain yang persentasenya cukup besar adalah memberi umpan balik/evaluasi/tanya jawab dan menjelaskan materi yang sulit yaitu masing-masing sebesar $15,00 \%$ dan $11,67 \%$. Sedangkan aktivitas siswa yang paling dominan adalah bekerja dengan sesama anggota kelompok dan mendengarkan/memperhatikan penjelasan guru yaitu 19,92\% dan 18,33\%. Aktivitas lain yang persentasenya cukup besar adalah, diskusi antar siswa/antara siswa dengan guru, dan membaca buku yaitu masing-masing 13,95 dan 12,71\%.

Pada siklus I, secara garis besar kegiatan belajar mengajar pembelajaran dengan metode pemberian balikan sudah dilaksanakan dengan baik, walaupun peran guru masih cukup dominan untuk memberikan penjelasan dan arahan karena model tersebut masih dirasakan baru oleh siswa.

Penerapan pembelajaran dengan metode pemberian balikan diperoleh nilai rata-rata prestasi belajar siswa adalah 66,94 dan ketuntasan belajar mencapai 69,44\% atau ada 25 siswa dari 36 siswa sudah tuntas belajar. Hasil tersebut menunjukkan bahwa pada siklus pertama secara klasikal siswa belum tuntas belajar, karena siswa yang memperoleh nilai $\geq 65$ hanya sebesar $69,44 \%$ lebih kecil dari persentase ketuntasan yang dikehendaki yaitu sebesar $85 \%$. Hal ini disebabkan karena siswa masih merasa baru dan belum mengerti apa yang dimaksudkan dan digunakan guru 
dengan menerapkan pembelajaran dengan metode pemberian balikan.

c. Refleksi

Dalam pelaksanaan kegiatan belajar mengajar diperoleh informasi dari hasil pengamatan (1) guru kurang baik dalam memotivasi siswa dan dalam menyampaikan tujuan pembelajaran, (2) guru kurang baik dalam pengelolaan waktu, dan (3) siswa kurang begitu antusias selama pembelajaran berlangsung.

d. Revisi

Pelaksanaan kegiatan belajar mengajar pada siklus I ini masih terdapat kekurangan, sehingga perlu adanya revisi yaitu (1) guru perlu lebih terampil dalam memotivasi siswa dan lebih jelas dalam menyampaikan tujuan pembelajaran dimana siswa diajak untuk terlibat langsung dalam setiap kegiatan yang akan dilakukan, (2) guru perlu mendistribusikan waktu secara baik dengan menambahkan informasi-informasi yang dirasa perlu dan memberi catatan, dan (3) guru harus lebih terampil dan bersemangat dalam memotivasi siswa sehingga siswa bisa lebih antusias.

\section{Siklus II}

a. Tahap perencanaan

Pada tahap ini peneliti mempersiapkan perangkat pembelajaran yang terdiri dari rencana pelajaran 2, LKS, 2 , soal tes formatif II dan alat-alat pengajaran yang mendukung. Selain itu juga dipersiapkan lembar observasi pengelolaan pembelajaran dengan metode pemberian balikan dan lembar observasi aktivitas guru dan siswa.

b. Tahap kegiatan dan pelaksanaan

Pelaksanaan kegiatan belajar mengajar untuk siklus II dilaksanakan pada tanggal 17 September 2010 di Kelas III.a dengan jumlah siswa 36 siswa. Dalam hal ini peneliti bertindak sebagai guru, sedangkan yang bertindak sebagai pengamat adalah dua orang guru. Adapun proses belajar mengajar mengacu pada rencana pelajaran dengan memperhatikan refisi pada siklus I, sehingga kesalahan atau kekurangan pada siklus I tidak terulang lagi pada siklus II. Pengamatan (observasi) dilaksanakan bersamaan dengan pelaksanaan belajar mengajar.

Pada akhir proses belajar mengajar siswa diberi tes formatif II dengan tujuan untuk mengetahui tingkat keberhasilan siswa dalam proses belajar mengajar yang telah dilakukan. Instrument yang digunakan adalah tes formatif II.

Dari hasil penelitian yang diperoleh, bahwa aspek-aspek yang diamati pada kegiatan belajar mengajar (siklus II) yang dilaksanakan oleh guru dengan menerapkan pembelajaran dengan metode pemberian balikan mendapatkan penilaian yang cukup baik dari pengamat. Maksudnya dari seluruh penilaian tidak terdapat nilai kurang. Namum demikian penilaian tersebut belum merupakan hasil yang optimal, untuk itu ada beberapa aspek yang perlu mendapatkan perhatian untuk penyempurnaan penerapan pembelajaran selanjutnya. Aspek-aspek tersebut adalah memotivasi siswa, membimbing siswa merumuskan kesimpulan/ menemukan konsep, dan pengelolaan waktu.

Dengan penyempurnaan aspekaspek di atas dalam penerapan pembelajaran dengan metode pemberian balikan diharapkan siswa dapat menyimpulkan apa yang telah mereka pelajari dan mengemukakan pendapatnya sehingga mereka akan lebih memahami tentang apa yang telah mereka lakukan.

Aktivitas guru yang paling dominan pada siklus II adalah membimbing dan mengamati siswa dalam menemukan konsep yaitu $21,67 \%$. Jika dibandingkan dengan siklus I, aktivitas ini mengalami peningkatan. Aktivitas guru yang mengalami penurunan adalah memberi umpan balik/evaluasi/tanya jawab $(16,67 \%)$, menjelaskan materi yang sulit $(15,00)$. Meminta siswa mendiskusikan dan menyajikan hasil kegiatan $(8,33 \%)$, dan membimbing siswa merangkum pelajaran $(6,67 \%)$.

Sedangkan untuk aktivitas siswa yang paling dominan pada siklus II adalah Bekerja dengan sesama anggota kelompok 
yaitu $(21,04 \%)$. Jika dibandingkan dengan siklus I, aktivitas ini mengalami peningkatan. Aktivitas siswa yang mengalami penurunan adalah mendengarkan/memperhatikan penjelasan guru $(17,92 \%)$. Diskusi antar siswa/antara siswa dengan guru $(13,75 \%)$, menulis yang relevan dengan KBM (7,71\%) dan merangkum pembelajaran (6,67\%). Adapun aktivitas siswa yang mengalami peningkatan adalah membaca buku $(12,08 \%)$, menyajikan hasil pembelajaran (4,58\%), menanggapi/mengajukan pertanyaan/ide $(5,42 \%)$, dan mengerjakan tes evaluasi $(10,83 \%)$.

Nilai rata-rata prestasi belajar siswa adalah 74,27 dan ketuntasan belajar mencapai $80,56 \%$ atau ada 29 siswa dari 36 siswa sudah tuntas belajar. Hasil ini menunjukkan bahwa pada siklus II ini ketuntasan belajar secara klasikal telah mengalami peningkatan sedikit lebih baik dari siklus I. Adanya peningkatan hasil belajar siswa ini karena setelah guru menginformasikan bahwa setiap akhir pelajaran akan selalu diadakan tes sehingga pada pertemuan berikutnya siswa lebih termotivasi untuk belajar. Selain itu siswa juga sudah mulai mengerti apa yang dimaksudkan dan diinginkan guru dengan menerapkan pembelajaran dengan metode pemberian balikan.

c. Refleksi

Dalam pelaksanaan kegiatan belajar diperoleh informasi dari hasil pengamatan yaitu (1) memotivasi siswa, (2) membimbing siswa merumuskan kesimpulan/menemukan konsep, dan (3) pengelolaan waktu.

d. Revisi Rancangan

Pelaksanaan kegiatan belajar pada siklus II ini masih terdapat kekurangankekurangan. Maka perlu adanya revisi untuk dilaksanakan pada siklus II antara lain:

1) Guru dalam memotivasi siswa hendaknya dapat membuat siswa lebih termotivasi selama proses belajar mengajar berlangsung.
2) Guru harus lebih dekat dengan siswa sehingga tidak ada perasaan takut dalam diri siswa baik untuk mengemukakan pendapat atau bertanya.

3) Guru harus lebih sabar dalam membimbing siswa merumuskan kesimpulan/menemukan konsep.

4) Guru harus mendistribusikan waktu secara baik sehingga kegiatan pembelajaran dapat berjalan sesuai dengan yang diharapkan.

5) Guru sebaiknya menambah lebih banyak contoh soal dan memberi soal-soal latihan pada siswa untuk dikerjakan pada setiap kegiatan belajar mengajar.

\section{Siklus III}

a. Tahap Perencanaan

Pada tahap ini peneliti mempersiapkan perangkat pembelajaran yang terdiri dari rencana pelajaran 3 , LKS 3 , soal tes formatif 3 dan alat-alat pengajaran yang mendukung. Selain itu juga dipersiapkan lembar observasi pengelolaan pembelajaran dengan metode pemberian balikan dan lembar observasi aktivitas guru dan siswa.

b. Tahap kegiatan dan pengamatan

Pelaksanaan kegiatan belajar mengajar untuk siklus III dilaksanakan pada tanggal 24 September 2016 di Kelas III.a dengan jumlah siswa 36 siswa. Dalam hal ini peneliti bertindak sebagai guru, sedangkan yang bertindak sebagai pengamat adalah dua orang guru. Adapun proses belajar mengajar mengacu pada rencana pelajaran dengan memperhatikan refisi pada siklus II, sehingga kesalahan atau kekurangan pada siklus II tidak terulang lagi pada siklus III. Pengamatan (observasi) dilaksanakan bersamaan dengan pelaksanaan belajar mengajar.

Pada akhir proses belajar mengajar siswa diberi tes formatif III dengan tujuan untuk mengetahui tingkat keberhasilan siswa dalam proses belajar mengajar yang telah dilakukan. Instrumen yang digunakan adalah tes formatif III. 
Aspek-aspek yang diamati pada kegiatan belajar mengajar (siklus III) yang dilaksanakan oleh guru dengan menerapkan pembelajaran dengan metode pemberian balikan mendapatkan penilaian cukup baik dari pengamat adalah memotivasi siswa, membimbing siswa merumuskan kesimpulan/ menemukan konsep, dan pengelolaan waktu.

Penyempurnaan aspek-aspek diatas dalam menerapkan pembelajaran dengan metode pemberian balikan diharapkan dapat berhasil semaksimal mungkin. Aktivitas guru yang paling dominan pada siklus III adalah membimbing dan mengamati siswa dalam menemukan konsep yaitu $21,67 \%$, sedangkan aktivitas menjelaskan materi yang sulit dan memberi umpan balik/evaluasi/tanya jawab menurun masing-masing sebesar $(10,00 \%)$ dan (11,67\%). Aktivitas lain yang mengalami peningkatan adalah mengaitkan dengan pelajaran sebelumnya $(10,00 \%)$, menyampaikan materi/strategi /langkahlangkah (13,33\%), meminta siswa menyajikan dan mendiskusikan hasil kegiatan (10,00\%), dan membimbing siswa merangkum pelajaran $(10,00 \%)$. Adapun aktivitas yang tidak mengalami perubaahn adalah menyampaikan tujuan $(6,67 \%)$ dan memotivasi siswa $(6,67 \%)$.

Sedangkan untuk aktivitas siswa yang paling dominan pada siklus III adalah Bekerja dengan sesama anggota kelompok yaitu $(19,17 \%)$ dan mendengarkan/ menperhatikan penjelasan guru $(18,75 \%)$, aktivitas yang mengalami peningkatan adalah membaca buku siswa (14,16\%) dan diskusi antar siswa/antara siswa dengan guru $(14,38 \%)$. Sedangkah aktivitas yang lainnya mengalami penurunan.

Nilai rata-rata tes formatif sebesar 80,86 dan dari 36 siswa yang telah tuntas sebanyak 32 siswa dan 4 siswa belum mencapai ketuntasan belajar. Maka secara klasikal ketuntasan belajar yang telah tercapai sebesar 88,89\% (termasuk kategori tuntas). Hasil pada siklus III ini mengalami peningkatan lebih baik dari siklus II. Adanya peningkatan hasil belajar pada siklus III ini dipengaruhi oleh adanya peningkatan kemampuan guru dalam menerapkan pembelajaran dengan metode pemberian balikan membuat siswa menjadi lebih terbiasa dengan pembelajaran seperti ini sehingga siswa lebih mudah dalam memahami materi yang telah diberikan.

c. Refleksi

Pada tahap ini akah dikaji apa yang telah terlaksana dengan baik maupun yang masih kurang baik dalam proses belajar mengajar dengan penerapan pembelajaran dengan metode pemberian balikan. Dari data-data yang telah diperoleh dapat duraikan sebagai berikut:

1) Selama proses belajar mengajar guru telah melaksanakan semua pembelajaran dengan baik. Meskipun ada beberapa aspek yang belum sempurna, tetapi persentase pelaksanaannya untuk masingmasing aspek cukup besar.

2) Berdasarkan data hasil pengamatan diketahui bahwa siswa aktif selama proses belajar berlangsung.

3) Kekurangan pada siklus-siklus sebelumnya sudah mengalami perbaikan dan peningkatan sehingga menjadi lebih baik.

4) Hasil belajar siswa pada siklus III mencapai ketuntasan.

d. Refisi Pelaksanaan

Pada siklus III guru telah menerapkan pembelajaran dengan metode pemberian balikan dengan baik dan dilihat dari aktivitas siswa serta hasil belajar siswa pelaksanaan proses belajar mengajar sudah berjalan dengan baik. Maka tidak diperlukan revisi terlalu banyak, tetapi yang perlu diperhatikan untuk tindakah selanjutnya adalah memaksimalkan dan mempertahankan apa yang telah ada dengan tujuan agar pada pelaksanaan proses belajar mengajar selanjutnya penerapan pembelajaran dengan metode pemberian balikan dapat meningkatkan proses belajar mengajar sehingga tujuan pembelajaran dapat tercapai. 


\section{Pembahasan}

\section{Ketuntasan Hasil belajar Siswa}

Melalui hasil penelitian ini menunjukkan bahwa pembelajaran dengan metode pemberian balikan memiliki dampak positif dalam meningkatkan prestasi belajar siswa. Hal ini dapat dilihat dari semakin mantapnya pemahaman siswa terhadap materi yang disampaikan guru (ketuntasan belajar meningkat dari sklus I, II, dan III) yaitu masing-masing 69,44\%, $80,56 \%$, dan $88,89 \%$. Pada siklus III ketuntasan belajar siswa secara klasikal telah tercapai.

\section{Kemampuan Guru dalam Mengelola Pembelajaran}

Berdasarkan analisis data, diperoleh aktivitas siswa dalam proses pembelajaran dengan metode pemberian balikan dalam setiap siklus mengalami peningkatan. Hal ini berdampak positif terhadap prestasi belajar siswa yaitu dapat ditunjukkan dengan meningkatnya nilai rata-rata siswa pada setiap siklus yang terus mengalami peningkatan.

\section{Aktivitas Guru dan Siswa Dalam Pembelajaran}

Berdasarkan analisis data, diperoleh aktivitas siswa dalam proses pembelajaran fisika pokok bahasan pengukuran (waktu, sudut, luas, volume dan satuannya) pembelajaran dengan metode pemberian balikan yang paling dominan adalah bekerja dengan menggunakan alat/media, mendengarkan/ memperhatikan penjelasan guru, dan diskusi antar siswa/antara siswa dengan guru. Jadi dapat dikatakan bahwa aktivitas siswa dapat dikategorikan aktif.

Sedangkan untuk aktivitas guru selama pembelajaran telah melaksanakan langkah-langkah pembelajaran dengan metode pemberian balikan dengan baik. Hal ini terlihat dari aktivitas guru yang muncul di antaranya aktivitas membimbing dan mengamati siswa dalam mengerjakan kegiatan LKS/menemukan konsep, menjelaskan materi yang sulit, memberi umpan balik/evaluasi/tanya jawab dimana prosentase untuk aktivitas di atas cukup besar.

\section{KESIMPULAN}

Dari hasil kegiatan pembelajaran yang telah dilakukan selama tiga siklus, dan berdasarkan seluruh pembahasan serta analisis yang telah dilakukan dapat disimpulkan sebagai berikut:

1. Pembelajaran pembelajaran dengan metode pemberian balikan memiliki dampak positif dalam meningkatkan prestasi belajar siswa yang ditandai dengan peningkatan ketuntasan belajar siswa dalam setiap siklus, yaitu siklus I $(69,44$, siklus II $(80,56 \%)$, siklus III $(88,89 \%)$.

2. Penerapan pembelajaran dengan metode pemberian balikan mempunyai pengaruh positif, yaitu dapat meningkatkan motivasi belajar siswa yang ditunjukan dengan rata-rata jawaban siswa yang menyatakan bahwa siswa tertarik dan berminat pembelajaran dengan metode pemberian balikan sehingga mereka menjadi termotivasi untuk belajar.

\section{UCAPAN TERIMA KASIH}

Ucapan terimakasih yang sebesarsebesarnya saya sampaikan kepada Kepala Sekolah dan dewan guru pada SDN 02 Kota Bima yang telah memberikan kesempatan untuk melakukan penelitian ini.

\section{DAFTAR PUSTAKA}

Achmadi dan Supriyanto. (1990). Faktorfaktor yang Mempengaruhi Prestasi Belajar. Bandung: Remaja Rosdakarya.

Arikunto, S. (2001). Dasar-dasar Evaluasi Pendidikan. Jakarta: Bina Aksara.

Arikunto, S. (2002). Prosedur Penelitian Suatu Pendekatan Praktek. Jakarta: Rineksa Cipta.

Combs. A.W. (1984). The Profesional Education of Teachers. Allin and Bacon, Inc. Boston. 
Djamarah, S.B. (1994). Guru dan Anak Didik dalam Interaksi Edukatif. Fakultas Tarbiyah IAIN Antasasi. Banjarmasin.

. (2002). Strategi Belajar Mengajar. Jakarta: Rineksa Cipta.

(2002). Psikologi Belajar. Jakarta: Rineksa Cipta.

Hamalik, O. (1992). Psikologi Belajar dan Mengajar. Bandung: Sinar Baru.

.(1999). Kurikulum dan Pembelajaran. Jakarta: Bumi Aksara.

Hasibuan. J.J. dan Moerdjiono. (1998). Proses Belajar Mengajar. Bandung: Remaja Rosdakarya.

KBBI. (1996). Edisi Kedua. Jakarta: Balai Pustaka.

Mukhlis, A. (Ed). (2003). Penelitian Tindakan Kelas. Makalah Panitian Pelatihan Penulisan Karya Ilmiah untuk Guru-guru se-Kabupaten Tuban.

Nur, M. (2001). Pemotivasian Siswa untuk Belajar. Surabaya. University Press. Universitas Negeri Surabaya.

Poerwodarminto. (1991). Kamus Umum Bahasa Indonesia. Jakarta: Bina Ilmu.

Rustiyah, N.K. (1991). Strategi Belajar Mengajar. Jakarta: Bina Aksara.

Sardiman, A.M. (1996). Interaksi dan Motivasi Belajar Mengajar. Jakarta: Bina Aksara.

Slameto, (1988). Evaluasi Pendidikan. Jakarta: Bina Aksara.
Soetomo. (1993). Dasar-dasar Interaksi Belajar Mengajar. Surabaya Usaha Nasional.

Sukidin, Basrowi dan Suranto. Manajemen Penelitian Tindakan Kelas. Surabaya:Insan Cendekia.

Usman, U. (2001). Menjadi Guru Profesional. Bandung: Remaja Rosdakarya. 